\title{
Detection of mitochondrial DNA mutations in human gingival tissues
}

\author{
Naoyuki Sugano, Kazuhiro Kawamoto, Hikaru Numazaki, Seidai Murai ${ }^{\S}$ and Koichi Ito \\ Department of Periodontology, Nihon University School of Dentistry, Tokyo 101-8310 and \\ ${ }^{8}$ Nihon University Research Center, Tokyo 101-8275
}

(Received 8 September and accepted 24 November 2000)

\begin{abstract}
The accumulation of mitochondrial DNA mutation is an important contributor to the aging process. Polymerase chain reaction (PCR) amplification was carried out on total DNA from gingival tissues of human subjects with ages of 19 to 64 years, and 5.0$\mathrm{kb}$ and 7.4-kb deletions were found in the mitochondrial genomes of these subjects. This is the first report of mitochondrial DNA deletion detectable in human gingival tissues. (J. Oral Sci. 42, 221-223, 2000)
\end{abstract}

Key words: aging; mitochondrial DNA mutation; gingival tissues; PCR.

\section{Introduction}

It is well known that the incidence and severity of periodontal disease are affected by age $(1,2)$. Periodontal tissues of aged individuals are believed to have impaired wound healing ability, although the precise nature of the underlying mechanism is unclear. Aging is a complex biological phenomenon associated with time-related degenerative processes. Recently, it has been proposed that accumulation of various somatic mutations in mitochondrial DNA (mtDNA) during life and the resulting decline of mitochondrial energy production are involved in the aging process. Somatic mtDNA mutation might occur in the general population, impairing both cell and tissue function in individuals of advanced age (3-8). Ikebe et al. (9)

Correspondence to Dr. Naoyuki Sugano, Department of Periodontology, Nihon University School of Dentistry, 1-8-13 Kanda-Surugadai, Chiyoda-ku, Tokyo, 101-8310, Japan

Phone: +81-3-3219-8087

Fax.: +81-3-3219-8349

E-mail address : sugano-n@dent.nihon-u.ac.jp reported the presence of mtDNA with a 5.0-kb deletion in the striatum of both patients with Parkinson's disease and aged subjects. Subsequently, the $5.0-\mathrm{kb}$ deletion was found to increase in various human tissues with age (1014).

In this study, polymerase chain reaction (PCR) amplification was carried out on total DNA from gingival tissues of human subjects with ages from 16 to 64 years, and $5.0-\mathrm{kb}$ and $7.4-\mathrm{kb}$ deletions were found in the mitochondrial genomes of these subjects. This is the first report of mtDNA deletion detectable in human gingival tissues.

\section{Materials and Methods}

\section{Preparation of DNA}

The chronic adult periodnotitis tissues (pocket depth $>5$ $\mathrm{mm}$ ) were collected during periodontal flap surgery from 5 patients ranging in age from 47 to 64 years and the healthy gingival tissue was collected during crown lengthening procedures from a 16 year-old patient. The patients did not have any clinical symptoms of systemic disease, and an informed consent was obtained from all subjects. High-molecular-weight DNA was isolated from the tissues with a QIAamp Tissue kit (Qiagen, Cartsworth, $\mathrm{CA}$ ) using the method recommended by the manufacturer.

\section{PCR analysis of deleted mt DNA}

The three different pairs of PCR primers used in this study. First, 5'-ACGAAAATCTGTTCGCTTCA-3' [L853] and 5'-AAATTTGAAATCTGGTTAGG-3' [H38] were used to amplify a $1.0-\mathrm{kb}$ fragment from mtDNA with a 7.4kb deletion. 5'-TGAACCTACGAGTACACCGA3'[L790] and5'- GGGGAAGCGAGGTTGACCTG-3' 

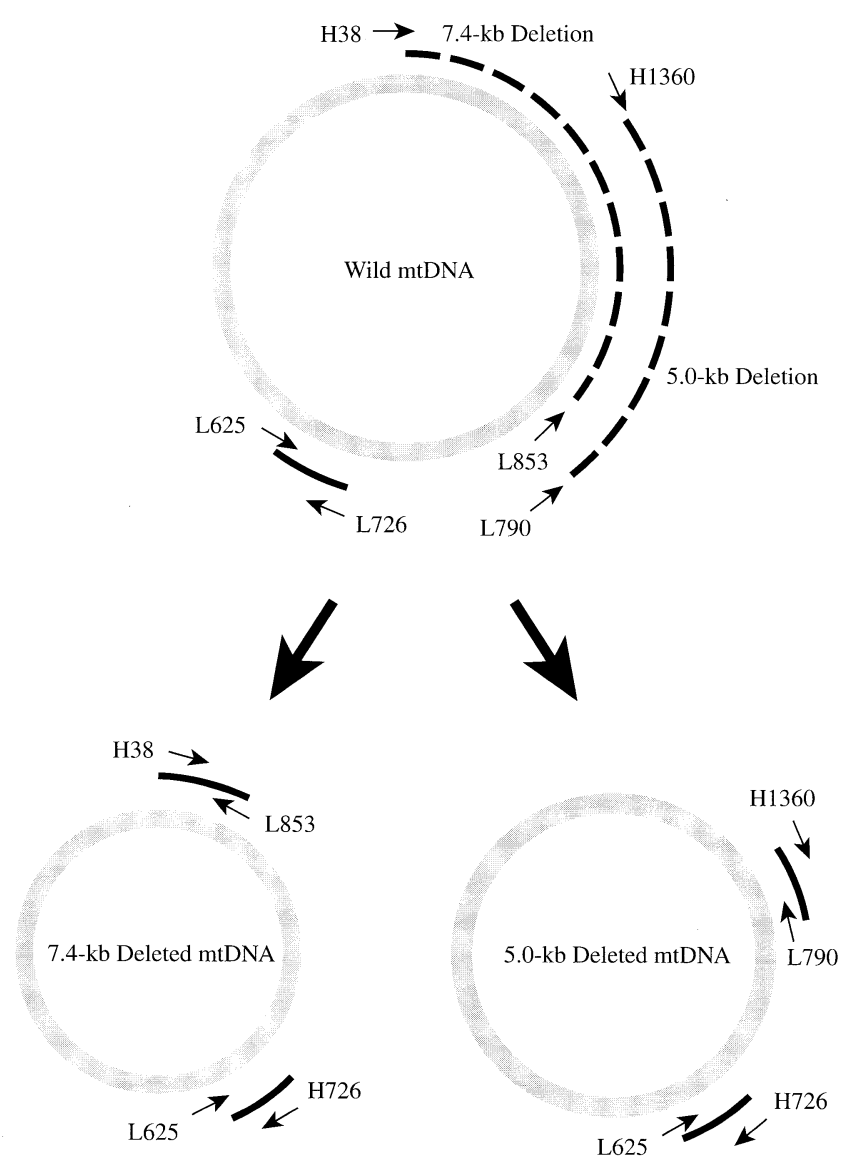

Fig.1 Schematic diagram of the technique used to selectively amplify deleted mtDNA genomes. Three different pairs of PCR primers were used. [L853] and [H38] were able to amplify a fragment from mtDNA with a 7.4$\mathrm{kb}$ deletion, but not from the wild-type mtDNA , [L790] and [H1360] were able to amplify a fragment from mtDNA with a $5.0-\mathrm{kb}$ deletion, but not from wild mtDNA, and lastly [L625] and [H726] were able to amplify a fragment from the wild and deleted mtDNA.

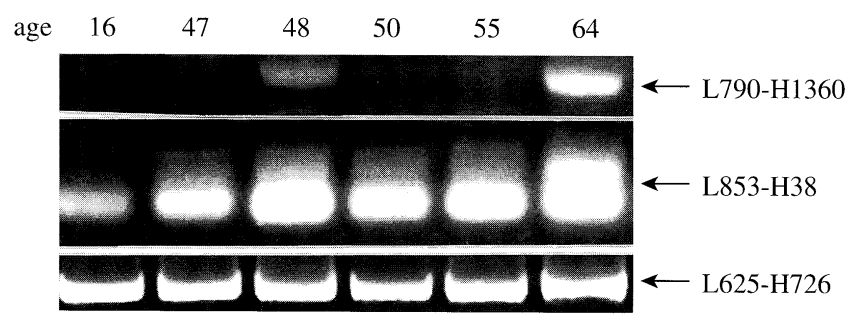

Fig.2 Detection of mtDNA deletion in tissues from 6 patients. The mtDNA fragments were amplified by PCR, separated on a $1 \%$ agarose gel and photographed after staining in ethidium bromide. The ages of the patients are indicated at the top of each lane.
[H1360] were used to amplify a $0.77-\mathrm{kb}$ fragment from mtDNA with a 5.0-kb deletion. Lastly, 5'TATAGTGGAGGCCGGAGCAG-3'[L625] and 5'GAATGAGCCTACAGATGATA-3' [H726] were used for the total mtDNA, amplifying a 1.0-kb fragment in a gene common to both the wild-type and deleted mt DNA (Fig.1) $(9,15)$. PCR was carried out with $1 \mu \mathrm{g}$ of total DNA in a tube of Ready-To-Go PCR Beads (Amersham Pharmacia Biotech. Inc., Piscataway, NJ). The thermal cycle employed involved denaturation for $15 \mathrm{~s}$ at $94^{\circ} \mathrm{C}$, annealing for 15 $\mathrm{s}$ at $50{ }^{\circ} \mathrm{C}$, and primer extension for $80 \mathrm{~s}$ at $72{ }^{\circ} \mathrm{C}$. Amplified samples were visualized on $1.0 \%$ agarose gels stained with ethidium bromide and photographed under UV light.

\section{Results}

By using PCR with L853-H38 primer pairs, we detected a product of the $1.0-\mathrm{kb}$ fragment in the DNA from all gingival tissues, which represents amplification of the region between the primers in the 7.4-kb deleted mtDNA (Fig.2). In addition, the intensity of the sample from the 16 year-old subject was lower than other samples. A 0.77 $\mathrm{kb}$ product was amplified with L790-H1360 primer pairs from DNA of 2 gingival tissue samples from the 48 and 64 year-old patients, indicating the presence of mtDNA templates bearing the $5.0-\mathrm{kb}$ deletion. PCR amplifications with L625-H726 primer pairs indicated the presence of mtDNA in the total DNA samples (Fig.2).

\section{Discussion}

The mtDNA deletions reported here, spanning the genes coding for Complex I subunits of the electron transport chain will cause a defect of Complex I, leading to decreased energy production (3). The percentage of hearts that have the 7.4-kb deletion increases with age, and the amount of the $5.0-\mathrm{kb}$ deltions increases in histologically normal hearts after age 40 (16). The $5.0-\mathrm{kb}$ deletion also accumulates in brain tissues in adults but not in children (17). These deletions accumulate much faster in tissues with high metabolic rate, oxidative damage and low proliferative index (4).

It has been reported that the age-associated increase in the level of any of the common deletions produced spontaneously is low $(<0.1 \%)(17)$. While the effect of this low level of deletions may not be significant, it is postulated that the deletions represent only a small proportion of the multitude of deletions and suggests that mutations that might exist and accumulate with age (18).

In summary, the presence of mtDNA deletions have been found in gingival tissues. One consequence of the accumulation of this deletion could be a progressive agerelated decrease of bioenergetic capacity, which in turn 
could impair normal cellular activities and compromise the ability of cells to adapt to various physiological stresses in gingival tissues. While this hypothesis requires further testing to assess whether the presence of deletions correlate with age, clinical parameters, risk factors and tissue metabolism, the presence of these deletions could be responsible for the aging of periodontal tissues.

\section{Acknowledgments}

This work was supported by Nihon University Research Grant for assistant, Sato fund Nihon University School of Dentistry and Japan Private School Promotion Foundation

\section{References}

1. Papapanou, P.N., Lindhe, J., Sterrett, J.D. and Eneroth, L. (1991) Considerations on the contribution of ageing to loss of periodontal tissue support. J. Clin. Periodontol. 18, 611-615

2. Machtei, E.E., Christersson, L.A., Grossi, S.G., Dunford, R., Zambon, J.J. and Genco, R.J. (1992) Clinical criteria for the definition of "established periodontitis". J. Periodontol. 63, 206-214

3. Wallace, D.C. (1992) Mitochondrial genetics: a paradigm for aging and degenerative diseases? Science 256, 628-632

4. Cortopassi, G.A., Shibata, D., Soong, N.W. and Arnheim, N. (1992) A pattern of accumulation of a somatic deletion of mitochondrial DNA in aging human tissues. Proc. Natl. Acad. Sci. U.S.A. 89, 7370-7374

5. Tanaka, M., Kovalenko, S.A., Gong, J.S., Borgeld, H.J., Katsumata, K., Hayakawa, M., Yoneda, M. and Ozawa, T. (1996) Accumulation of deletions and point mutations in mitochondrial genome in degenerative diseases. Ann. N.Y. Acad. Sci. 786, 102-111

6. Zhang, C., Baumer, A., Maxwell, R.J., Linnane, A.W. and Nagley, P. (1992) Multiple mitochondrial DNA deletions in an elderly human individual. FEBS Lett. 297, 34-38

7. Hayakawa, M., Sugiyama, S., Hattori, K., Takasawa, M. and Ozawa, T. (1993) Age-associated damage in mitochondrial DNA in human hearts. Mol. Cell Biochem. 119, 95-103

8. Ozawa, T. (1997) Genetic and functional changes in mitochondria associated with aging. Physiol.
Rev. 77, 425-464

9. Ikebe, S., Tanaka, M., Ohno, K., Sato, W., Hattori, K., Kondo, T., Mizuno, Y. and Ozawa, T. (1990) Increase of deleted mitochondrial DNA in the striatum in Parkinson's disease and senescence. Biochem. Biophys. Res. Commun. 170, 1044-1048

10. Ozawa, T., Tanaka, M., Sugiyama, S., Ino, H., Ohno, K., Hattori, K., Ohbayashi, T., Ito, T., Deguchi, H., Kawamura, K., Nakane, Y. and Hashiba, K. (1991) Patients with idiopathic cardiomyopathy belong to the same mitochondrial DNA gene family of Parkinson's disease and mitochondrial encephalomyopathy. Biochem. Biophys. Res. Commun. 177, 518-525

11. Schapira, A.H., Gu, M., Taanman, J.W., Tabrizi, S.J., Seaton, T., Cleeter, M. and Cooper, J.M. (1998) Mitochondria in the etiology and pathogenesis of Parkinson's disease. Ann. Neurol. 44, Suppl. 1, 8998

12. Linnane, A.W., Baumer, A., Maxwell, R.J., Preston, H., Zhang, C.F. and Marzuki, S. (1990) Mitochondrial gene mutation: the ageing process and degenerative diseases. Biochem. Int. 22, 1067-1076

13. Hayakawa, M., Torii, K., Sugiyama, S., Tanaka, M. and Ozawa, T. (1991) Age-associated accumulation of 8-hydroxydeoxyguanosine in mitochondrial DNA of human diaphragm. Biochem. Biophys. Res. Commun. 179, 1023-1029

14. Yen, T.C., Su, J.H., King, K.L. and Wei, Y.H. (1991) Ageing-associated $5 \mathrm{~kb}$ deletion in human liver mitochondrial DNA. Biochem. Biophys. Res. Commun. 178, 124-131

15. Hayakawa, M., Hattori, K., Sugiyama, S. and Ozawa, T. (1992) Age-associated oxygen damage and mutations in mitochondrial DNA in human hearts. Biochem. Biophys. Res. Commun. 189, 979-985

16. Ozawa, T. (1995) Mechanism of somatic mitochondrial DNA mutations associated with age and diseases. Biochim. Biophys. Acta. 1271, 177189

17. Cortopassi, G.A. and Arnheim, N. (1990) Detection of a specific mitochondrial DNA deletion in tissues of older humans. Nucleic. Acids. Res. 18, 6927-6933

18. Arnheim, N. and Cortopassi, G. (1992) Deleterious mitochondrial DNA mutations accumulate in aging human tissues. Mutat. Res. 275, 157-167 